\title{
Anthropology at Work
}

\section{My 20 Years as World Bank Development Anthropologist}

\author{
Maritta Koch-Weser
}

This is a personal record. I describe my work at the World Bank for over 20 years, telling you how we began a new and continuously evolving professional practice four decades ago, and to what effect. I hope to transmit to students of a next generation the causes that development anthropology stands for, and to pass on my passionate conviction that it must remain a mainstream discipline in the twentyfirst century.

\section{Beginnings}

In the 1970s, development anthropologists began to work on economic development issues in the world's poorest corners and among indigenous populations. For me, as one of them, development anthropology became a lifelong passion, a way to contribute meaningfully towards the larger social and environmental challenges of our times.

The term Development Anthropology had come up in the early 1970s as a variant of sociology, designating the operationally oriented transition from theory to applied analytical and design work. My own interest had been triggered early-on during my 1970-1972 doctoral fieldwork on "Yoruba Religion in Brazil". Two experiences, two planning failures, had sharpened my sense for the fundamental value of social and cultural understanding in local development work-and for the rather simple opportunities that were being missed:

The first experience was the rough, poorly conceived involuntary resettlement of Favela

Catacumba in Rio de Janeiro to the distant fringes of the city. Some of the followers of the

M. Koch-Weser ( $\square)$

Earth3000, Bieberstein, Germany

e-mail: mkochweser@earth3000.org 


\begin{abstract}
Macumba and Umbanda rituals I was studying were forcefully resettled. In their previous favela location in central Rio de Janeiro, they had kept live animals behind their shackssacrificial animals to be offered to the Orixas, typically a goat, or some chicken or doves-a firm element of their Afro-Brazilian rituals. Now, in their new social housing flats, I found animal husbandry — smelly goats — on the third floor, in peoples' new bathrooms-an absolutely disgusting, unhygienic mess. Why, I asked, had nobody looked into peoples' lives, religion, and special needs beforehand? Better design—simply a place outside for the goat - could probably have been provided at no additional cost.

The second experience was a visit to the early-stage construction of the grandiosely planned, first east-west Transamazon Highway in 1971. We witnessed the intrusion of gigantic forest clearing equipment, the horrific screeching of huge, falling trees, and the conversion of landscapes as entire forest tracts were removed. This destruction of nature's grand rainforest, scars left alongside visibly failing human resettlements, left a deep impression. These settlements, mechanically planned by land surveyors and engineers, were social and economic failures. Close to Altamira in the State of Para, semi-cleared forest lands had been distributed to landless peasant families from far away, drought-stricken areas in Brazil's arid Northeast. These people had no familiarity with the plants, soils, insects, and snakes surrounding them in Amazonia. Some also suffered from malaria. Whatever they had known about agricultural cycles in their native arid Sertão environment had become irrelevant. Surely the unfortunate settler families could have at least have fared better with appropriate induction and socio-cultural designs.
\end{abstract}

As a student, I had already become convinced that participant observation-the art of listening to people, observing interrelationships in communities, and gaining knowledge about the local web of history and religion, must all inform any effective tailoring of aid. Michael Cernea's later, seminal 1985 book was rightly called "Putting People First".

\title{
Practice
}

When I refer to Development Anthropology, I think of practice rather than theory. In development planning and project implementation we seek to make useful contributions through field work, careful participant observation, interviewing, walking into houses, kitchens and storage rooms, and by observing gender roles, power relationships, power struggles, and the interplay and differences across communities.

As development anthropologists, we participate in endeavors which seek the best ways to improve local livelihoods, health, nutrition, incomes, land rights, women's rights, access to credit, and more. Our analysis can give voice and promote inclusion-through community participation, attention to the social roles of men, women, and minorities, and indigenous safeguards.

Development anthropologists must bring to the task an appetite for field work,for listening, observing, interviewing with compassion—and yet with a cool head, systematizing what they learn in the course of open, interactive interviews and participant observation. They must measure success in terms of development outcomes on the ground. 


\section{Participant Observation}

Participant observation means going to the end of the line. As a development anthropologist, you should travel endless rural roads, where most government official will have never set foot. The objective is to look and to observe, to ask people - and to put yourself into the place of your interviewees to the greatest extent possible, across cultural barriers, finding your very own, pragmatic shortcuts to get at least some sense of what development looks like "from within".

A plain, positive example always stuck in my mind: We had asked Larry Salmen, a fellow anthropologist, to analyze the appropriateness of a World Bank financed social housing project in Guayaquil/Ecuador. Larry decided that participant observation meant not just interviewing new residents, but spending a few nights sleeping on the floor of one of the already finished housing units. This way he discovered a world beyond what the building engineers had previously registered-the world of noises and lack of privacy, the terrible heat and lack of ventilation, and more. Obviously, it does not take a social science PhD to check these, but the fact remains that in this case, just-in-time "participant observation" field work helped improve the design for these poor people's new houses-improvements that would not have happened otherwise.

Another example along those lines was my own discovery during a field visit in Karnataka, India. Here, houses lacked toilets, and this had caused problems, especially for women who feared going down to the snake infested river at night. Their problem had been addressed in the World Bank financed project I had come to supervise. To provide more safety, a village female toilet facility had been built close by at the edge of the village. As a woman, I could interview local womenexpecting, but not getting, nods of approval. Something seemed strange. I insisted - earning endless giggles - to personally visit the site of supposed improvement, the female toilet facility. I walked into a walled rectangle, followed only up to the entrance by a sizable crowd from the village. Inside there was absolutely nothing — no toilets, no water, no pipes-only clean, dry sand. Visibly, nobody had ever used this fraud as a toilet. I invited the hesitant Chief Minister of the State to come inside to inspect the place. I hope the crooks who had failed to deliver a true toilet facility were punished.

\section{Courage to Experiment}

Projects are social laboratories. At the outset, the acceptance of new designs is uncertain, and must be checked over the years. Will midwives stop using rusty knives or dusty concoctions on the umbilical cords they cut? Will expecting mothers take advantage of pre-natal care? Will community decisions to manage forests sustainably on Nepalese hillsides be respected or enforced? 
Interdisciplinary cooperation and team work are key. In field situations anthropologists will work alongside colleagues specialized as engineers, agronomists, health or education experts, or economists. When innovations are contemplated, doubts often center on attitudinal or cultural uncertainties. Will land purchase credit work-will it be used by sharecroppers, and will borrowers indeed pay their dues? When vaccinations are offered, will mothers bring their children? When water user associations or cooperatives are established, will the members make them work, and stick to common rules? In cases such as these, development anthropologists take on their share of project risks.

In most cases, taking the risks turned out to have been worthwhile. Some of the very best development innovations of the 1980s came from organizations outside the public sector. For want of precedent, they had to be imagined. In Bangladesh, Mohammed Yunus successfully experimented with at least three major innovations in parallel: the principal one being a reliance on promoting a leading developmental role for women (as he saw it); group micro-credit; and the introduction of the Grameen Phone - a technical innovation for connecting largely illiterate communities to the market. Fathom how courageous he was. No previous studies could have proven him right, only close follow-up with women's and community groups could provide proof of concept over time. Grameen phone became a national success. It will take more such imagination, and more and larger experimentation to attain the United Nations Social Development Goals (SDGs) in the coming years.

\section{Tasks then and Now}

The war on poverty is still with us - now in a world which has doubled its population since 1970 . We live in a predominantly urban world now, rather than a mostly rural one then. Yet the tasks we faced 4-5 decades ago are still with us, especially in sub-Saharan Africa and so many more remaining poverty niches on earth. Average national statistics have often improved significantly, hiding the fact that severe poverty niches have been left behind nevertheless. Today the challenge is to focus "surgically" on those niches.

The record of development achievements over the past 50 years is not bad. Many battles have been won: agricultural productivity is up, and statistics on child mortality, life expectancy, literacy rates have improved significantly. Biodiversity, climate and ocean protection have all made enormous strides. Now the achievements of yesteryear must be upheld or completed way beyond the lifetime of past development loans - among them the protection of most vulnerable minorities and indigenous people, the education of girls and women, the just compensation and resettlement of people affected by infrastructure works, and the integrity of protected nature areas and World Heritage Sites around the world.

Priorities have shifted. Fields to which development anthropologists must now especially contribute include: 
- the urgent task of salvaging and preserving indigenous knowledge, before it vanishes forever;

- the task of helping societies overcome outdated labels, stereotypes and assumptions - uncovering socio-cultural undercurrents in governance, religion, drug trade, and internet-based community formation;

- tasks related to migration: the integration of migrants, patterns of remittances, and intercultural integration; and

- the task of fostering global cooperation in preserving this earth. The task is global, but much of the needed action remains a local, behavioral and cultural challenge.

\section{Downsides}

In an international development agency, development anthropologists work at an intermediary level. The development agency work routine with its short field visits rarely allows for well calibrated "own" field research. Therefore, a fleeting visit by a World Bank anthropologist can never substitute for much needed in-depth studies, which need to be commissioned and carried out by professionals fluent in local dialect and culture.

In my work experience I regularly depended on local experts. But our own short visits were useful starting blocks. They served to let us scan for priority sociocultural issues, and they allowed us to develop terms of reference for appropriate in-depth analysis, commissioned with local universities and experts for the life-span of a project-for advice in project design and monitoring, and for independent evaluation.

Development projects involve dynamic, multi-year social processes, some foreseeable, others not. No project I know of - if it involved people at all and not just a single physical construction site-has ever been implemented successfully without intelligent adjustments over the course of time. Social design assumptions must always be tested "on the ground", within different communities, and in complex not entirely foreseeable institutional, political or market contexts.

In our group of colleagues we experienced, painfully, that the impact of our work also very much depended on proper timing. It is frustrating when social expertise is brought in too late, in a trouble-shooting mode, or in the perfunctory manner of ticking off a list of formal requirements, without any real care for the results. Once things get off track, they will be far more difficult to turn around.

I experienced such situations in several of my early field assignments. One was a Honduran afforestation project supported by the Organization of American States in the late 1970s, where we found local farmers pulling out "project" tree seedlings that had been planted for erosion control on steep hillsides. It was an untenable project design: hungry peasants replaced tree seedlings with the corn that they needed to eat. Afforestation could not succeed without mitigation of extreme hunger and landlessness. Far more positive examples for "social forestry" were developed later in India 
and Nepal, where from the start the emphasis was on social consensus to implement communal strategies for re-growth and highly controlled use, such as the gathering of firewood.

Another example was the World Bank's first-ever Nutrition Improvement Project in the state of Sergipe in Northeast Brazil in the early 1980ies. This project was testing and comparing four design experiments to improve child nutrition. At mid-term we found that all experiments were failing for one reason or another. Even worse, simple routines of driving small children on trucks to weighing stations had met with immense fear and anger of the left behind parents. Had social expertise been employed earlier, at least such culturally unacceptable design features might have been avoided.

Around the same time, a further early example was a USAID funded settlement project in San Julian, which I reviewed at the request of the World Bank. In a tropical forest region in Bolivia, north of Santa Cruz de la Sierra, the project attempted to settle land-starved Indios from the Bolivian Altiplano $3000 \mathrm{~m}$ above. Much like the failing resettlements I had seen as a student in the Brazilian Amazon, the Aymara in their woolen garb, estranged from their intricate social and agricultural highland rules of life, and afraid of snakes and insects would not succeed in this sweltering environment. The basic design of the settlement project was fraught, and belated social expertise could point out, but not correct failure.

\section{Upsides}

Projects are experiments - searches for the most effective development opportunities. Cases, like the ones just mentioned, where the original project design turned out to be fatally flawed, were fortunately very few over the years - and in Latin America they all belonged to the late 1970s and early 1980s. Later, as greater attention had been paid in project design to social factors, timely monitoring and evaluation became key so that emergent problems could be caught, reviewed, and used for mid-course corrections. Refinements of social (but also of technical) designs continued throughout the multi-year life of a project-taking account of unforeseen events or attitudes on project performance.

My list of monitoring and evaluation "successes," where good monitoring alerted early on to problems and the need to correct course could fill a book. Let me give you three examples:

I recall unwanted outcomes of the land distribution schemes run by INCRA, the Brazilian Agrarian Reform Agency in the Brazilian Amazon, in the new frontier state of Rondonia in the early 1980ies. Breaking a tradition of sharecropper exploitation, peasants had been assigned their own plots of land. For the first time in their lives they had become proud and independent land owners. What happened? Soon enough they repeated the only economic model they had ever experienced, now turning other rural laborers into "their" sharecroppers.

In Mexico, the PIDER program-Programa Integrado de Desarrollo Rural—as well as other rural development projects cosponsored by IFAD (for example, in the Oaxaca 
highlands) had at its core the work with communities, which could opt for rural development measures that the villages wished to prioritize. "Listening to the people", the question of power and voice in community meetings, turned out to be a challenging task. For example, I witnessed that men wanted soccer fields, instead of asking for a better well to free their women from hauling water bucket-by-bucket from more than $100 \mathrm{~m}$ depth in dry southern Yucatan. In one village which had opted for and received a "cattle unit", I remember the local way of "benefit-sharing" aligned with local power structures. The project financed "cattle unit" consisted of the animals, establishment of new pastures, and fences to protect them. On supervision we found that the richer half of the village had appropriated the cattle (and already quickly sold them for money to improve their houses). This left the poorer, less powerful people stranded with useless fences and pastures - and without cattle. As a result, economic progress was nil, except for the better roofs that the cattle sellers had put on their houses. Monitoring and Evaluation provided fast learning on how to more carefully conduct community work, benefitting subsequent village planning under this nation-wide rural development program.

As a third example, let me mention rural development in Kigoma, at the western edge of Tanzania, bordering Rwanda. A project designed to improve rural productivity was in its third year of implementation, when we came to carry out a mid-term evaluation. Already, the project was seen by government officials as a failure, because the project-financed public storage facilities had remained largely empty. Nevertheless, during our field visit agricultural production under this project seemed to be successful and thriving. Interviews with peasants did not provide any plausible answers on why the marketing component was failing, and why the warehouses remained empty. Soon enough we could see what was happening: long lines of people, wares on their backs, were winding up the path towards the border. On foot the production was carried up the mountain into adjacent Rwanda, where prices several times higher than in Tanzania level could be caught in those days.

\section{Fields of Danger}

The job of a development anthropologist can be dangerous. Going to "the end of the line"-especially in frontier areas where the rule of law is fragile-or to isolated groups who do not understand the purpose of your visit, can be tough.

I helped design and worked on the first Amerindian Protection Projects in Northwest Brazil, and also in the wider area of influence of the Carajas Iron Ore project in Brazil. To fly in one-engine planes in order to visit recently contacted tribal groups like the Urueuwauwau, in Rondonia-leads to unpredictable situations.

My colleague Daniel Gross once called from Rondonia where he had wanted to see close up whether the health post at the Cinta Larga indigenous reserve had been duly constructed. He was attacked and never managed to even get off the FUNAI government plane. As it turned out, the Indios had been befriended and bribed by illegal diamond and gold "garimpeiros", who regularly brought them gifts (e.g. much appreciated frozen chicken). The Cinta Larga did not wish to see this relationship interrupted by Government authorities, with whom Daniel Gross, a World Bank anthropologist, had arrived. Dan just about escaped with his life.

Also related to the protection of indigenous lands under a World Bank project, I once arrived in the Brazilian State of Bahia at the Kiriri de Mirandela indigenous reserve. Before we reached the Reserve, we were "greeted" by a most aggressive 
group of local farmers, their sharp hoes high in the air, who saw the government Jeep and objected to a program that was advancing competing indigenous land rights (as required under Brazilian law). I was 7 months pregnant and doubly worried. Praise the day when you arrive home safely after facing armed conflict over indigenous lands.

Or worse, in a forestry project in southern Colombia, a guerrilla zone in the 1980ies, you ride and walk to reach a group of farmers attending a cocoa treatment workshop. No telephones can announce your visit. As you surprise the group, each of them grabs the gun that they hold between their legs, ready to fire on the unexpected visitors. Here a World Bank project was taking place in a war zone. Every anthropologist working in those far-off places where development is most needed will have stories like these.

\section{Authenticity}

I found it impossible to always remain as neutral and respectful of local culture as I thought outside "objective" observers should be. A scene from highland Bolivia: A small child fell, was badly wounded, and cried desperately. Nobody acted and I picked it up-although bystanders thought this inappropriate and ridiculous.

Among the Nambikwara Indios in Brazil twins were born, and this was considered a bad omen. Traditionally one had to be killed (a custom probably rooted in age old survival methods-reflecting the excessive challenge of feeding and carrying two infants instead of one). The medical project staff tried to salvage both children, explaining there would be enough food.

Equally, how could you hold back when you hear of female circumcision, child marriages, or harmful techniques applied by midwives? Development Anthropologists come with their own cultural baggage.

\section{My World Bank Years: In Retrospect}

In the late 1970s sociologist and development anthropologist positions were not advertised, simply because they did not exist. My first "foot in the door" was a brief consultant assignment in Bolivia, where a rural poverty alleviation project had met with unexpected opposition from the local population. As it turned out, the rural roads had been widened, in some cases touching on the edges of fields where here and there ancestors had been buried. It was literally an unspeakable problem, but one local anthropologists would readily point out to me when I visited. Similarly, intricate age-old local labor exchange systems had not been taken into account in this project-and hence the Dutch cooperative specialist ended up having a hard time. With findings like these I and the first handful of social scientists began to conquer new places at the World Bank, case by case. 
Robert S. McNamara, World Bank President since 1968, had brought a healthy measure of impatience and moral compassion to the development task, dissatisfied with the snail pace of poverty eradication globally. In his 1973 Nairobi Speech he framed the challenge: “. . This is absolute poverty: a condition of life so limited as to prevent realization of the potential of the genes with which one is born; a condition of life so degrading as to insult human dignity- and yet a condition of life so common as to be the lot of some $40 \%$ of the peoples of the developing countries."

Convinced that economic development could not be reached in the poorest corners of the world by infrastructure projects alone, McNamara set up the Agriculture and Rural Development Department as a hub for piloting innovations. Back then, poverty was still concentrated in the rural world: $70 \%$ of people in developing nations lived in rural areas (in contrast, today $70 \%$ are urban). In addition, the World Bank commissioned its first analyses and programs for health, nutrition, education, population control, and environment. McNamara pressed for measurable outcomes, and the monitoring and evaluation of project results became standard. An ultimately truly transformative path had been established, but even with steep growth in lending and a multi-sectoral broadening of the development agenda, reality rarely matched the speed of change McNamara that would have liked to see.

\section{A Foot in the Door}

Here's how I got started. Equipped with my German doctoral degree, I started teaching courses in Latin American and Development Anthropology at George Washington University in Washington DC in 1975. In parallel I began in 1977 to work occasionally as a consultant for international organizations in our university's immediate Washington DC neighborhood-first for the Organization of American States, then The American Association for the Advancement of Science, and then for the World Bank, which I joined on a full-time basis in 1980.

My first 3 years as a World Bank consultant (1977-1980) were both fascinating and frustrating. I worked on the outer fringes of what was then a singularly economics- and engineering-oriented organization. Consultants were able to observe and recommend, but they had to leave operational decisions entirely to the staff members who had hired them. As a junior consultant working alongside my teaching jobs, I had no leverage in decision making, and remained stuck in the smallest, windowless office.

Nevertheless, getting my foot in the World Bank door turned out to be the best direction my professional life could have taken. It was my good fortune that I was eventually hired into the hub of innovation, the Agriculture and Rural Development Department under the great leadership of Montague Yudelman and Leif Christoffersen, and in the direct neighborhood of Michael Cernea, the World Bank's first ever rural sociologist. Twenty fascinating years filled with challenging field work lay ahead, eventually landing me with more than my share of 
responsibilities out there in Latin America, North Africa, Sub-Saharan Africa, South and East Asia, and some countries of the former Soviet Union.

I became a full-time staff member in 1980, I believe as the third professional social scientist that the organization had ever hired. When I left in 1998, there must have been close to 200 social scientists; tremendous change had taken place. With Michael Cernea's arrival in the 1970s, social disciplines had gained their intellectual champion, and, under Michael's leadership, more and more social scientists were hired-first as consultants, and later as staff. We came together in an intense learning-by doing process in the 1980s and throughout the 1990s. An informal internal platform - the World Bank's Sociological Working Group-interconnected us. To avoid the usual problems of too many bureaucratic silos and not enough time to interact as a community, we regularly got together over brown-bag lunches, sharing experiences and getting inspired by outside speakers.

We all shared a steep and sometimes arduous learning curve. With hindsight, major blind spots remained in the early 1980ies. To name a few, micro-credit, cultural heritage, disaster preparedness, fighting corruption, and analyzing local governance-all were as yet not on the screen. Governance constraints were suppressed - to the detriment of longer-term structural change: To shape projects into efficient spearheads, the management of World Bank projects often established temporary institutional enclaves where good people were hired for decent salaries. Once projects ended, the previous advantage turned into a drawback, because of a lack of insertion into the overall national patterns of governance and payrolls. This led to some discontinuities and setbacks.

Another blind spot was the consideration of ethnic minorities and indigenous people - a thorny issue as World Bank projects began to reach into far-away frontier lands in Indonesia and Brazil, and into ethnically complex regions in Africa.

Environment may have been the biggest blind spot of them all: resettlement programs like Transmigration in Indonesia and POLONOROESTE in Brazil, programs which transformed vast and pristine rainforest areas into agricultural settlements, would be unthinkable today. Environmental lending was equally unthinkable in the early 1980s. Direct investments into environmental protection and institution building only came on line years later, when economic tools to value returns on national investments into environmental management were developed in the run-up to the 1992 Earth Summit. The new economic thinking and recognition of biodiversity and climate protection as core global concerns were consolidated under the leadership of Andrew Steer in the World Development Report on "Environment and Development." To his credit, McNamara had at least begun to institutionalize environmental work at the World Bank, creating a first, tiny specialized unit already in the early 1970 s. 


\section{Uphill Battles}

Things were not easy to begin with. Finance Ministry officials from World Bank borrower countries balked at demands for environmental and indigenous safeguards. And our supposedly "soft science" was hardly appreciated by our World Bank peers and managers.

My own tough experience in this regard was the negotiation of indigenous and environmental safeguards and monitoring and evaluation obligations under the POLONOROESTE loans for Brazil-the very first program in Latin America dealing with settlements in Amazonian frontier rainforest areas. Our Brazilian Borrowers gave assurances most reluctantly. Top management at the World Bank remained convinced that the financing of an orderly land occupation process could bring lasting benefits to poor settlers in this malaria-ridden frontier region. Once the program got underway, Evaluation reports soon pointed out massive problems, which are well described in Robert Wade's contribution to this book.

But in this uphill battle there was also growing appreciation of our roleespecially among agronomists and irrigation experts leading project work at the field level. Among social science colleagues we took strength from the practical usefulness of our inputs, which seemed to matter for people on the ground-the intended "beneficiaries" of World Bank projects.

I found my work meaningful and exciting at a very personal level. At the University, I had earlier taught students about the lousy Indigenous Protection Service of Brazil in the 1960s; but then, under a series of World Bank financed projects, I had become able to bring about programs for indigenous land demarcation in Brazil, or to channel social and health programs to indigenous communities in Mexico. It was a marvelous opportunity "to walk the talk". I have among my best memories the village level work under the Mexican PIDER program which had started in the late 1970s, and the integrated, multi-sectoral rural development work in Northeast Brazil in the early 1980s. In both cases, findings during field visits translated clearly into project design and implementation.

We found ourselves on an inspiring, yet perilous "uphill" path. We had to fight and take risks - all along aware of our fragile knowledge base: World Bank missions were extremely short, with little time to scratch more than the surface. In the early years we fought our way, case by case, theme by theme, confronting many issues for the first time. We matured conceptual frameworks and "case-law", but there were, as yet, no binding guidelines. Michael Cernea, Gloria Davis, and Robert Goodland became the foremost promoters of the subsequent development of social and environmental ground rules. Shelton Davis added the fight for rules relating to indigenous peoples. 


\section{Looking Back}

So what did we achieve? Looking back at our two decades as World Bank development anthropologists or sociologists, to which products and to which innovations could we contribute?

We started with project work, and built sets of guidance and institutional norms based on lessons learned and cases lived. Key products to which my colleagues and I specifically contributed can be characterized in two groups: systemic improvements and innovations within the World Bank system, and project-cases.

In their days, many amounted to battlefronts, with their successes and setbacks. Based on my early experiences which had taken me beyond Latin America also to Burkina Faso, Benin, Cameron, Tanzania, Algeria and even Portugal (which at the time was still a World Bank Borrower), I joined the drive for new, systemic instruments.

\section{Innovations}

To negotiate with Borrowers and Co-financiers, clear and binding codes of conduct for social and environmental safeguards became indispensable. Especially in lending operations which involved large works-dams and roads-we needed firm directives that could be easily understood by our counterparts. Project-based rulesdevelopment spanned a broad thematic spectrum-indigenous peoples, water user associations, involuntary resettlement, cultural heritage and, above all, routine social and environmental impact assessment requirements. Sociologists and environmentalists joined hands, developing detailed guidance. In parallel, transparency and accountability were fostered by an independent Operations Evaluation Department, and later also an Ombudsman Function. In addition, public access to environmental impact assessments was instituted.

We also initiated institutional innovations. For example, I wrote some of the first proposals for what was to become the Global Environment Facility. We launched studies on the need to eliminate perverse fiscal incentives (Binswanger \& Mahar) which were undercutting environmental protection programs. We looked into debtfor-nature swaps and other imaginative new forms of environmental finance. I had oversight of several innovative World Bank programs, among them a first renewable energy unit, that served all regions. I established the first disaster preparedness facility supporting projects for more resilience in earthquakes, floods, or high storms; we hoped to prevent loss of life in future catastrophic events among the poorest populations living in unsafe housing on hillsides, or in low-lying flood plains. We not only listened carefully to criticisms from NGOs, but we also hired some of their environmental experts. We promoted and got Board approval for performance-based lending instruments-Adaptable Lending, and in particular 
Learning \& Innovation loans. It would take another book to write up these and more stories.

\section{A Record of Project Cases}

What kind of projects did I work on the most? Let me highlight some categories:

Rural Development. It was my good fortune, my "foot in the door" that when I started work at the World Bank, I was able to carry out useful field workinterviewing farmers and working with local counterparts in their native language all over Latin America. To begin with, I worked on programs in Bolivia, Northeast Brazil, Mexico, and later also in Colombia. When a staff member or consultant fell ill, I readily substituted, also in Monitoring and Evaluation training courses for counterparts in Brazil or in Costa Rica.

Land tenure improvement. Landlessness and pathways to ownership are thematic areas relevant in much of Latin America to this day-not easy, complex in technical and social terms, but worth every effort. My list of hard tasks also included responsibility for a "Land Tenure Improvement" Project for Northeast Brazil. I was designated as project officer half way through this complex but most interesting process designed to recover land occupied illegally by larger owners. Cadastral maps identified such parcels, with the objective to redistribute them to landless peasants and, in turn, to provide these with technical and credit support.

Frontier Development. In 1980, as soon as I had joined the regular World Bank staff, I was immediately put to work last minute on the appraisal of the World Bank's first lending program in Amazonia - the POLONOROESTE Program, combining road, integrated rural development, and Amerindian and environmental protection in frontier areas in Mato Grosso and Rondonia. I highlighted this program above already, as hard to negotiate and a milestone in Monitoring and Evaluation.

This was a first attempt of the World Bank to bring order into a most disorderly frontier occupation process in Mato Grosso and the just established State of Rondonia. It had all started with the BR 364 trunk road built by the military. The rationale for World Bank involvement was that settlers and regional development would be better off with agro-ecological zoning, decent health, education, and extension services, and environmental and indigenous safeguards. I was given responsibility for the last-minute development of two components: Monitoring and Evaluation and Amerindian Protection. Already, in the first two years of this program, the multi-disciplinary Independent Evaluation contracted out to the University of Sao Paulo had begun to document numerous violations of the Loan Agreements-gross violations of the environmental and Amerindian safeguard agreements that the Brazilian Government and the World Bank had signed. This became an uncontrollable frontier settlement. Satellite images show how POLONOROESTE, along with the "Transmigration" program in Indonesia, literally changed the face of the earth. Today, the scars of fishbone-like deforestation can be seen from outer space. It was an ugly story involving poor settlers, rich speculators 
(not funded by the World Bank), lenient government officials who allowed invasions of unsuitable lands and titled them after a small waiting period, and it became a story of impotent, underfunded environmental and indigenous protection agencies at the federal and state levels. A small consolation: the large indigenous reserved and nature protection areas demarcated under the World Bank program remain largely intact to this day-positive exceptions in an ecological disaster area.

Mining. The early 1980s were a time of mega-projects. The Brazilian Carajas Iron Ore project financed by World Bank, Japan and the European Union was one of them. It developed the then largest iron ore mine on our planet, and, in addition, an $800 \mathrm{~km}$ railroad from the inland mine site to the shipping harbor of Sao Luis do Maranhão in Northeast Brazil. Here my task was again the design of an Amerindian Protection Project, in a radius of $100 \mathrm{~km}$ of the mine and the railroad. Together with Companhia Vale do Rio Doce we identified 13 Reserves which needed to be properly protected and demarcated by FUNAI, the Indian Protection Agency. Later, as the project was implemented, additional tiny groups of hitherto uncontacted Indios were detected by aerial photography.

The larger project region included one of the most contentious areas of land struggle in Brazil, the "Bico do Papagaio" south of Marabá, and Serra Pelada-a wild cat goldmine with thousands of gold seekers (a place close to hell which the photography of Sebastiao Salgado has engraved in history). To make matters worse, environmental and Amerindian protection, painstakingly designed under the World Bank project, were soon undercut by a parallel central Government Program, the so-called Greater Carajas Program. It promoted land settlements and charcoal production, a driver of deforestation, for local production of pig iron. Nevertheless, at least the Amerindian Protection Program continued to be implemented, much to the credit of one highly committed professional, Maria de Lourdes Davies Freitas, at Companhia Vale do Rio Doce.

Resettlement was associated with mega infrastructure projects for hydropower and irrigation. Because resettlement became such a major social challenge in many projects, it is addressed in a special section here in our book. Difficult as it will always be, resettlement remains indeed one of the most daunting tasks, as the world modernizes and changes. Today, with more wind, gas, and solar renewable energy options, we hope to see fewer displacements of people by large hydro-power and irrigation dams. But just think of the many roads that wait to be widened in high density India and elsewhere in Asia. Guidelines for as fair as possible resettlement schemes must be upheld and adjusted to new situations-always with the objective to not only substitute for losses, but also to seize positive opportunities to improve livelihoods of affected people.

My own encounters with resettlement issues included in Brazil the development of a Social and Environmental Master Plan for the Brazilian Power Sector and, in that context, the development of the Itaparica resettlement plan. They also included Yacireta in Argentina and Paraguay, irrigation and power projects in Karnataka, India, the Xiaolangdi Hydropower and Flood control dam in China, and the Nam Theun Dam in Laos. Working on resettlement is tough: Social design can only 
attempt to produce mitigation plans, but can never eliminate the basic pain of involuntary resettlement.

New Products. Shaping first-ever National Environmental Programs counts among my best, most positive memories. The Brazilian National Environmental Program led the way, funding the build-up of a National Environment System with specialized Government agencies, Protected Areas, and Coastal Zone Management, and social and environmental impact assessment routines. Later Mexico, Venezuela, Philippines, and more followed. National Environmental Programs came up around the time of the first Rio Earth Summit, when environmental management and protection got due recognition around the world as a government sector in need of institution building.

\section{Governance and Accountability}

The work of our generation of development anthropologists has been challenging and fulfilling. Yet, looking back, so many things could have turned out better. Over the years, it is hard not to become cynical with hindsight: How many good Government Commitments have my colleagues and I seen signed in World Bank Loan Agreements-initially signed and upheld by the government in power at loan signing, but subsequently not honored after the next election.

Too often attitudes of irresponsibility have undermined project outcomes. Too often we have seen successor governments feeling less and less bound by their predecessors' commitments. The lack of long-term responsibility structures is clearly one most important, unresolved problem. Looking ahead, a key question is how long-term responsibility systems might be locked-in more reliably, for example by setting aside long-term finance in escrow accounts for the completion of 10-20 year resettlement consolidation processes.

Above all, unkept promises have to be addressed more squarely. Lending should be suspended more often, more swiftly and more rigorously when agreements are broken, even if this might include leveraging the full weight of an overall country lending program. One loan must condition another-cross-referencing of compliance is needed.

\section{How to Get Better?}

I left the World Bank after some 20 years, looking ahead-convinced that development finance needed to make a greater difference. In so many respects we had done well, but not well enough.

I remain convinced that international assistance programs often need to (1) start smaller, and faster-to make them more responsive to local community needs, (2) that environmental and social impact assessments need to become more central 
early-on in any project preparation process, and (3) that we need stronger enforcement and long-term responsibility systems.

(1) Start smaller, and faster-responsive to local community needs: Elephantine, slow bureaucratic processes-dishing out of large loans at low cost-per-\$ invested is often misrepresented as being "efficient". However, if efficiency is instead defined in terms of results-per- $\$$ on the ground smaller packages, smaller yet faster starts, turn out to be far more effective. In many cases, it is wise to first experiment with social strategies (e.g. in water user associations or communal social forestry). This is why Learning and Innovation loans were introduced in the 1990s, which allowed for quick loans in amounts smaller than 5 million\$ without formal Board approval.

Adaptable Program Loans and Learning and Innovation Loans (LILs) were approved by the Bank's Board of Directors on September 4, 1997, especially as a tool for working in poorly understood social contexts, with programs needing experimentation and constant adjustments in “.... the kind of poverty-oriented project where the learning was occurring during this particular (project implementation) period", as Gloria Davis put it in her oral history recorded in June 2004.

Special credit for supporting the Learning and Innovation Loans goes to Robert Picciotto. In his oral history recorded November 1, 2000, he states ..."the adaptable lending products (Learning and Innovation Loans and Adaptable Program Loans) were the result of work I personally did in my spare time in cooperation with Maritta Koch-Weser. The new products reflected the experience I had gained in two decades of project work. The new learning and innovation cycle involves listening, piloting, demonstrating and mainstreaming. I think the LIL is a very promising instrument. The basic difference between the adaptable loans and the blueprints kind of project loans is a sense of constant adaptation and learning. Wolfensohn right away understood the value of the product when we made a presentation to him. The Board liked it. And I think the majority of the staff liked it. So now we have to evaluate how well it's working. My guess is that there are problems because people use the new instruments while still having a blueprint mentality.... So, I think the evolution of the new project cycle is not yet complete".

(2) Environmental and social impact assessments need to be started earlier in project preparation. They have become mandatory, and this is an achievement that we wanted. However, at closer look, this has often also turned them into lastminute perfunctory exercises, carried out when all else has been planned. Opportunities for better design can be lost in this way: When the design of a dam has been decided, alternatives in terms their environmental and social impacts are beyond the point. 
In projects which may require major resettlements (I remember Jamuna Bridge in Bangladesh as a case in point) the social assessment should in fact start from the very beginning, to register before all else who actually would be affected, and as such be entitled for resettlement benefits under a potential later project. Provisions for legal recourse of affected people, and minorities in particular, need to be built into project design.

Downstream risks need to be understood early on as well. Some not-so-large projects are wolves in sheep's skin: first, a low impact project, only to be followed some years later by larger, much higher impact phases (the Belo Monte hydropower project in Brazil is a recent example).

And, finally, in development assistance organizations we must carry out selfassessments, recognizing limits to our own implementation and supervision capacity. For example, at the World Bank we were fortunate not to finance the Three Gorges Dam in China, which came with resettlement of about 2 million people. This order of magnitude would surely have surpassed the loan supervision capabilities of international development agencies.

(3) Stronger responsibility and enforcement systems. Our multi-year responsibility systems are intrinsically weak. Over five and more years of project implementation, the cast of characters at both the World Bank and in the Borrower Government can be expected to change. Institutional memory and the political will to adhere to challenging demands of yesteryear tend to fade on both sides. The local population and social and environmental safeguards bear the brunt.

For me, a most frustrating example was the Itaparica Dam Resettlement program, where-once the reservoir had been filled and Government had changed, commitments to complete the irrigation districts for resettled communities were not honored. If, instead of written commitments only, a resettlement escrow fund had been established, funds for completion-as-promised might have remained available.

I am convinced that to assure systems of compensation over what we already know will be a 10-20 year resettlement consolidation period requires setting aside and locking-up corresponding funds from the start, way beyond a project's limited financing period proper.

Formalistic reliance on local law (which often is not in keeping with international standards) should not be acceptable, but clear "own" rules of development agencies are needed to take their place.

\section{Years: In Stages}

From 1977-1990, I worked as a "sociologist"-initially as a team member in rural development programs in Latin America and Africa, and then also as a member of that Department's Monitoring and Evaluation unit. Soon I also worked on social and environmental assignments in Latin America outside the agriculture sector-in the forestry, mining, and energy sectors. My responsibilities grew. I became a 
full-fledged project officer, responsible for multidisciplinary projects and programs, first in Brazil, and then all over Latin America. And before long, I joined the advance team, alongside other colleagues, who promoted the establishment of the first-ever social and environmental safeguard rules at the World Bank.

Since the late 1980s I worked as a Division and then Department manager in the field of environmentally and socially sustainable development. For several years, I headed the "Environmental Assessments and Programs" Division of the newly established Environment Department within the World Bank's central policy vicepresidency. Later yet, I returned to the operational side of the World Bank, working for several years as Head of the Asia Environment Division on the entire South and East Asia portfolio. Finally, following yet another overall reorganization of the World Bank-I became Director of the Latin America \& Caribbean Department for Environmentally and Socially Sustainable Development, a position I held until the end of 1998.

\section{Beyond World Bank Days}

When I left the World Bank, I joined the World of NGOs, continuing the very same social and environmental quest as head of IUCN (The International Union for the Conservation of Nature), and then Earth3000, an organization I founded in 2001 in support of innovations in governance for environment and development. For many years since, I have continued to support development anthropology and environmental causes, among them the Global Exchange for Social Investment, World Heritage Watch, and as leader of a program on modern Amazonia at University of Sao Paulo, in Brazil. As Board Member I have over many years shared responsibilities with organizations, businesses, and academic institutions engaged in nature conservation, social banking and impact investment, climate, and academic programs.

Always, inside the World Bank and in the international world of NGOs I have enjoyed playing my part in a larger orchestra-working alongside and being inspired by like-minded colleagues.

\section{Years Well Spent}

My career at the World Bank allowed me to care for causes that had stayed with me since student days. As a student, Brazil had been my learning ground. I had seen extreme poverty - starvation in the face of drought, child mortality so frequent in a hospital without medicines in Penedo, Alagoas/Brazil that there were not enough cardboard boxes to carry the dead babies to the cemetery. A German nurse worked there, desperately trying her best. Now, working at the World Bank, I could engage in rural development in some of those very same regions, helping to design and run 
integrated rural development programs that sought to increase incomes, access to credit, basic health care and primary education.

At the University I had written an article about the fate of Brazil's declining remnant indigenous population - and the ways in which they had fared so badly under the Indigenous Protection Service during the years of Brazil's military regime. Now, I could help convince the Brazilian Government of the 1980s to demarcate land and to implement indigenous legislation under the country's new Constitution.

I had first seen environmental destruction in the Amazon as a student. Now I had a chance to design and supervise first environmental Protection Programs in Rondonia, Mato Grosso, and the Carajas Regions in Para and Maranhão, and later to lead preparation of first National Environmental Programs in Brazil and Mexico. As satellite pictures show, at least indigenous and environmental reserves have so far been mostly spared from the onslaught of forest destruction.

\section{Next?}

To a next generation of development students I recommend to move beyond academic desk work soon, and to experience field assignments early on. Find out how it feels - may be applied Development Anthropology is for you. Our world is replete with technology and finance-help make them work for the neediest people and for a livable future on our blue planet.

Maritta Koch-Weser was one of the very first social scientists at the World Bank. Since 1977, she spent over two decades as a leader in the growing social and environmental practice at the World Bank, working in Latin America, Asia, Africa, and Eastern Europe. In this contribution to Michael Cernea's Festschrift, she recalls challenges that she and her colleagues saw as development anthropologists, and contemplates today's needs. Above all, the author hopes to stimulate professional interest in Development Anthropology among a next generation of students and practitioners.

Open Access This chapter is licensed under the terms of the Creative Commons Attribution 4.0 International License (http://creativecommons.org/licenses/by/4.0/), which permits use, sharing, adaptation, distribution and reproduction in any medium or format, as long as you give appropriate credit to the original author(s) and the source, provide a link to the Creative Commons license and indicate if changes were made.

The images or other third party material in this chapter are included in the chapter's Creative Commons license, unless indicated otherwise in a credit line to the material. If material is not included in the chapter's Creative Commons license and your intended use is not permitted by statutory regulation or exceeds the permitted use, you will need to obtain permission directly from the copyright holder.

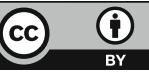

